\title{
Pemanfaatan Limbah Bambu Menjadi Asap Cair sebagai Pengawet Alami pada Struktur Kayu
}

\author{
Lady Dian Ridolf 1), S.P. Abrina Anggraini 2), Maria Odelia Gani ${ }^{3)}$, Tio Noviadi 4) \\ 1,2,3,4 Program Studi Teknik Kimia, Fakultas Teknik, Universitas Tribhuwana Tunggadewi-Malang \\ E-mail: Ladydianridolf97@gmail.com. No. HP: 082341043152
}

\begin{abstract}
ABSTRAK
Kualitas kayu yang semakin menurun mengakibatkan keresahan bagi masyarakat terutama para pengrajin kayu dan industri karet. Hal ini dikarenakan, semakin banyaknya penggunaan bahan pengawet kayu yang membahayakan kesehatan. Salah satu cara yang dapat dilakukan untuk mengawetkan kayu, yaitu melalui pemanfaatan limbah pertanian atau biomassa seperti bambu dengan proses pirolisis. Tujuan penelitian ini untuk menentukan kualitas asap cair dengan limbah bambu sebagai pengawet alami kayu. Pada penelitian dilikakukan proses pirolisis dan pemurnian asap cair dari bambu menggunakan reaktor pirolisis pada kondisi operasi optimum dimana panjang pipa penghubung kondensor yang digunakan adalah $43 \mathrm{~cm}$ pada suhu $250^{\circ} \mathrm{C}$ selama $1,5 \mathrm{jam}$. Hasil penelitian ini menunjukkan rendemen asap cair yang diperoleh dari masing-masing pipa penghubung kondensor $43 \mathrm{~cm}$ adalah 19,5 dengan nilai $\mathrm{pH}$ dan fenol 2,43 dan $1,15 \%$.
\end{abstract}

Kata kunci: Asap cair; pengawet alami; rendemen asap cair; pH dan fenol.

\begin{abstract}
The quality of the wood that declining result in unrest for the public especially the craftsmen of wood and rubber industry. This is because, more use of wood preservatives that endanger health. One of theways that can be done to preserve the wood, namely through the utilization of agricultural waste or biomass such as bamboo by pyrolisis. The purpose of this research was to determine the quality of liquid smoke with bamboo as a preservative atural waste wood. Research on the pyrolysis is done and liquid smoke purification of bamboo pyrolysis reactor using on optimum operating condirions where the length of the connecting pipe condenser used is $43 \mathrm{~cm}$ at a temperature of $250{ }^{\circ} \mathrm{C}$ for 1.5 hours. The results of this study showed yield liquid smoke obtained from each of the connecting pipes of the condenser is $19.5 \mathrm{~cm} 43$ with the $p H$ and the phenol 2,43 and $1,15 \%$.
\end{abstract}

Keywords : liquid smoke; natural preservative; yield liquid smoke; $p H$ and phenol.

pengawet berbaya yang membahayan

\section{PENDAHULUAN}

Semakin hari masyarakat dibuat resah karena berkurangnya kualitas mebel yang dibuat oleh para pengrajin mebel. Hal itu ditandai dengan keadaan mebel yang tidak tahan lama atau mudah lapuk yang akhirnya menjadi sarang rayap, mebel yang dibuat juga seringkali dijumpai menggunakan bahan kesehatan manusia. Tidak hanya itu, kecurangan yang dilakukan oleh para pemebel juga sangat merugikan bagi pembeli mebel yang membayar harga mahal tetapi tidak sesuai dengan kualitas mebel yang diterima. Salah satu cara yang dapat digunakan untuk menjaga kualitas kayu dengan menggunakan asap cair sebagai pegawet alami yaitu melalui pemanfaatan limbah pertanian atau biomassa seperti bambu. Asap cair memiliki kemampuan 
untuk mengawetkan kayu terutama terhadap jamur pembusuk putih seperti jamur Ganoderma sp dan Paliporus alcularis. Asap cair hasil pirolisis ini bergantung pada bahan baku dan suhu pirolisis [1]. Asap cair yang dihasilkan oleh bambu memiliki rendemen tinggi yaitu $62.89 \%$ dibandingkan dengan hasil dari kayu-kayu yang lainnya. Potensi luas hutan bambu di Indonesia mencapai 2 juta ha dengan hasil lebih dari 3,8 ton/ha/tahun [2]. Di dalam proses produksinya, rendemen produksi bambu untuk mebel dan kerajinan sekitar 60\% dan 40\% menjadi limbah [3]. Bambu adalah salah satu limbah sisa kerajinan, sisa bangunan yang sangat mudah ditemui disekitar permukiman penduduk. Selama ini limbah bambu hanya dibuang ke lingkungan padahal limbah bambu dapat dimanfaatkan sebagai asap cair [4]. Bambu merupakan penghasil selulosa terbesar dibandingkan pohon pinus yaitu sekitar per ha 2-6 kali. Peningkatan biomassa pohon kayu hanya $2.5 \%$ per hari, sedangkan biomassa bambu meningkat 10 $30 \%$ per hari. Dalam 4 tahun bambu dapat dipanen, hal ini lebih singkat dibandingkan 8-20 tahun untuk jenis pohon kayu yang cepat tumbuh [5].

\section{Tabel 1. Komposisi Kimia Bambu}

\begin{tabular}{ll}
\hline Komponen & Kandungan \\
\hline Selulosa & $42.4-53.6$ \\
Lignin & $19.8-26.6$ \\
Pentosan & $1.24-3.77$ \\
Zat-Zat ekstraktif & $4.5-9.9$ \\
Air & $15-20$ \\
$\mathrm{Abu}$ & $1.24-3.77$ \\
$\mathrm{SiO} 2$ & $0.10-1.78$ \\
\hline \multicolumn{1}{c}{ Sumber: (Widya, 2006)[6] }
\end{tabular}

Asap cair merupakan hasil pembakaran secara langsung maupun tidak langsung (pirolisis) yang kemudian dikondensasikan, dari bahan yang mengandung senyawa lignin, hemiselulosa, selulosa dan senyawa karbon lainnya [7]. Asap cair hasil pirolisis ini tergantung pada bahan baku, temperatur/suhu pirolisis, kinerja alat pirolisis terutama reaktor dan kondensor. Komponen-komponen penyusun asap cair, meliputi: 1) Senyawa-senyawa fenol. . Senyawa Fenol merupakan senyawa antioksidan yang terdapat pada asap cair sehingga dapat memperpanjang masa simpan produk asapan. fenol juga dapat memberikan cita rasa dan warna yang khas pada produk yang dihasilkan. Kuantitas fenol pada kayu sangat bervariasi yaitu antara 10-200 mg/kg [8]. Beberapa jenis fenol yang biasanya terdapat dalam produk asapan adalah guaiakol, dan siringol; 2) Senyawa-senyawa Karbonil. Senyawa-senyawa Karbonil dalam asap cair memiliki peranan pada pewarnaan dan cita rasa produk asapan; dan 3) Senyawasenyawa asam. Nilai $\mathrm{pH}$ merupakan salah satu sifat kimia yang menentukan kualitas asap cair yang dihasilkan. Nilai $\mathrm{pH}$ rendah berarti asap yang dihasilkan berkualitas tinggi terutama dalam hal penggunaannya sebagai bahan pengawet makanan. Nilai $\mathrm{pH}$ yang rendah secara keseluruhan berpengaruh terhadap nilai awet dan daya simpan produk asap ataupun sifat organoleptiknya [9]. Selain bebas dari senyawa berbahaya, asap cair yang digunakan sebagai pengawet bahan pangan harus memiliki flavor yang dapat di terima konsumen. [10]

Reaktor pirolisis adalah alat yang digunakan untuk memproduksi asap cair yang terdiri dari tabung pirolisis, pipa penghubung kondensor, penangkap tar, kondensor, dan penampung asap cair. Pipa penghubung kondensor pada reaktor pirolisis memiliki peran penting untuk menghasilkan rendemen lebih banyak dan berkualitas karena hasil tar yang keluar melalui pipa penghubung reaktor harus keluar untuk mengurangi kadar tar dari asap cair yang dihasilkan. Agar mendapatkan asap cair yang berkualitas dan aman 
digunakan dalam pengawetan kayu maka diperlukan pipa penghubung kondensor yang mempunyai kinerja yang optimal sehingga dalam penelitian ini digunakan alat reaktor pirolisis dengan ukuran pipa penghubung kondensor $43 \mathrm{~cm}$. Pada penelitian ini akan dilakukan analisa yang meliputi rendemen asap cair, kadar fenol, nilai $\mathrm{pH}$, bau serta warna dari asap cair. Berdasarkan hal tersebut, peneliti tertarik untuk meneliti pengganti pengawet kayu yang aman bagi masyarakat dan pemanfaatan limbah biomassa sebagai bahan baku asap cair dengan penggunaan pipa penghubung kondensor $43 \mathrm{~cm}$.

\section{METODE PENELITIAN}

Metode penelitian yang akan digunakan dalam penelitian ini menggunakan metode eksperimental laboratorium. Bahan baku yang digunakan dalam penelitian ini adalah bambu. Bahan bakar pada proses pirolisis ini digunakan adalah gas elpiji. Peralatan yang digunakan dalam penelitian ini adalah alat reaktor pirolisis. Bambu terlebih dahulu dibersihkan selanjutnya dicacah dengan ukuran 8-10 cm secara manual, kemudian bambu yang telah dicacah dikeringkan dengan penjemuran secara langsung menggunakan bantuan matahari. Setelah

\section{HASIL DAN PEMBAHASAN}

Tabel 1. Hasil Rendemen Asap Cair, Fenol, pH, Warna dan Aroma

\begin{tabular}{ll}
\hline $\begin{array}{l}\text { Panjang Pipa Penghubung } \\
\text { Kondensor (cm) }\end{array}$ & 43 \\
\hline Rendemen Asap Cair $\mathbf{~ ( \% )}$ & 19,5 \\
\hline $\mathrm{pH}$ & 2,43 \\
\hline Fenol & 1,12 \\
\hline Warna & Merah \\
& Kecoklatan \\
\hline Aroma & Asap Kuat \\
\hline
\end{tabular}

\subsection{Rendemen Asap Cair}

bambu kering maka dilakukan proses pirolisis dengan suhu $250^{\circ} \mathrm{C}$ selama 2 jam. Proses pirolisis diawali dengan penimbangan bambu sebanyak $1,5 \mathrm{~kg}$ dan memasukkannya kedalam reaktor pirolisis kemudian dilakukan proses pembakaran (pirolisis) menggunakan bahan bakar LPG. Selama proses pirolisis berlangsung, dicatat waktu awal pirolisis dan waktu saat penetesan pertama asap cair. Setelah melewati proses pirolisis kemudian dilanjutkan dengan proses kondensasi. Proses kondensasi menghasilkan tiga produk, yaitu fraksi padat (arang), fraksi berat (tar) dan fraksi ringan (asap cair dan gas methan). Produk utama berupa asap cair hasil pirolisis ditampung dalam sebuah wadah. Proses pirolisis berakhir ditandai dengan tidak adanya asap cair yang keluar. Asap cair yang diperoleh diendapkan selama seminggu kemudian disaring menggunakan kertas whatman no. 42 dan diukur berapa banyak rendemen yang dihasilkan. Setelah itu, dilakukan analisa GC/MS dengan menggunakan indikator kadar fenol dan nilai pH. Selanjutnya asap cair tersebut diaplikasikan pada kayu dengan cara 1cc asap cair grade 3 dilarutkan dalam $300 \mathrm{ml}$ air, kemudian disemprotkan atau direndam kayu ke dalam larutan.

Pada Tabel 1. presentase rendemen asap cair yang dihasilkan pada keadaan pipa penghubung kondensor $43 \mathrm{~cm}$ sebesar 19,5\%. Hal ini dikarenakan pada saat proses pirolisis (pembakaran) berlangsung, kandungan air yang terdapat dalam bambu ikut menguap pada suhu $100^{\circ} \mathrm{C}$ dan mengalami kondensasi ketika uap air melalui kondensor sehingga meningkatkan jumlah kondensat asap cair yang dihasilkan. Rendemen asap cair dipengaruhi oleh suhu pada saat proses pirolisis dan juga dipengaruhi oleh kadar air yang terkandung pada bahan baku yang digunakan. Asap cair 
pada penelitian ini dihasilkan melalui proses kondensasi asap yang dikeluarkan reaktor pirolisis, dimana komposisi rendemen yang dihasilkan sangat dipengaruhi oleh sistem kondensasi, hal ini sesuai dengan yang dikemukakan oleh [11] yang menyatakan bahwa dalam pembakaran digunakan air sebagai medium pendingin agar proses pertukaran panas dapat terjadi dengan cepat. Pirolisis dengan penggunaan suhu yang terlalu tinggi dan waktu yang lama akan menyebabkan pembentukan asap cair yang akan berkurang hal ini dikarenakan suhu dari air pendingin semakin meningkat sehingga asap yang dihasilkan tidak akan terkondensasi secara optimal, sehingga untuk menghasilkan rendemen yang tinggi maka diperlukan proses kondensasi yang optimal dengan sistem pendingin yang dialirkan secara kontinu sehingga suhu dalam sistem pendingin stabil. Hal ini sesuai dengan pernyartaan [12] bahwa proses pirolisis akan menghasilkan asap cair yang maksimum jika proses kondensasinya berlangsung secara sempurna.

\subsection{Warna}

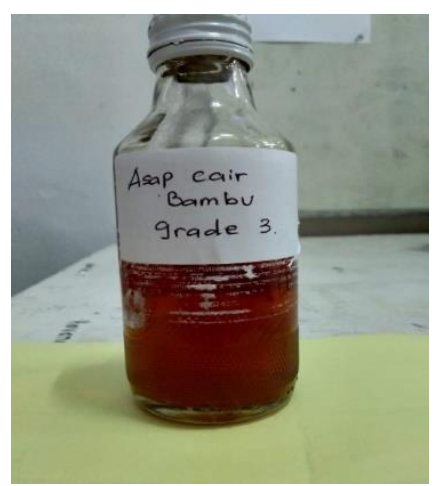

Gambar 1. Asap cair grade 3

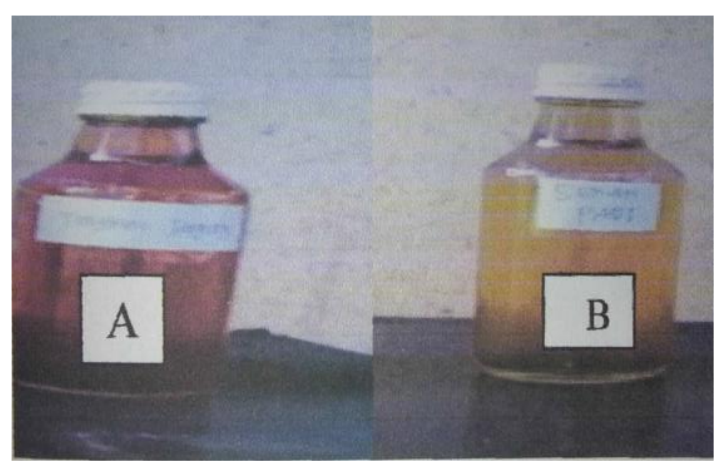

Gambar 2. : A. Tongkol Jagung, B. Sekam Padi (sumber : Elssy dan Olga, 2015) [13]

Dari hasil penelitian Ellsy dan Olga, (2015) menghasilkan warna dari asap cair berbahan dasar tongkol jagung dan sekam padi memiliki warna yang berbeda dengan hasil penelitian dengan penggunaan bahan baku bambu, dimana warna yang dihasilkan merah kecoklatan yang lebih pekat, warna yang di hasilkan dari proses pirolis dengan bahan baku bambu ini dipengaruhi dengan adanya senyawa karbonil. Karbonil memiliki peran yang penting pada warna dan cita rasa yang dihasilkan oleh asap cair [14].

\subsection{Aroma}

Dari hasil penelitian ini didapatkan hasil aroma asap cair yang sangat pekat aroma asapnya. Aroma pada asap cair dihasilkan dari kandungan fenol. Menurut [8], senyawa fenol sangat berperan dalam pemberian aroma asap.

\subsection{Kadar Fenol}

Pada Tabel 1. kadar fenol pada pipa penghubung kondensor ukuran $43 \mathrm{~cm}$ menunjukkan bahwa asap cair yang dihasilkan memiliki kualitas yang baik digunakan sebagai bahan pengawet dan penghambat kerusakan yang disebabkan oleh oksidasi lemak. Dikarenakan fenol merupakan senyawa penting yang terkandung dalam asap cair dimana fenol berperan sebagai antimikroba dan antioksidan. Menurut [15] menyatakan bahwa kandungan fenol pada asap cair hasil 
pirolisis pada berbagai temperatur dan waktu pirolisis bahwa semakin tinggi temperatur pirolisis maka kandungan fenol pun akan semakin meningkat. Kandungan fenol dengan penggunaan bahan baku bambu memiliki nilai yang cukup tinggi, hal ini dikarenakan kandungan lignin pada bambu yang besar sehingga kadar fenol yang peroleh juga cukup tinggi. Kadar fenol yang terdapat pada asap cair sangat dipengaruhi oleh komponen kimia yang terkandung di dalam bahan baku bambu seperti selulosa, hemiselulosa dan lignin, dimana semakin besar kandungan lignin pada bahan baku maka kandungan fenol dalam asap cair akan semakin besar [15].

\subsection{Nilai pH}

Nilai $\mathrm{pH}$ merupakan salah satu sifat kimia yang menentukan kualitas asap cair yang dihasilkan. Nilai $\mathrm{pH}$ yang dihasilkan dari pipa penghubung kondensor ukuran 43 sebesar 2,43. Hal ini menunjukan bahwa kadar fenol dan nilai $\mathrm{pH}$ berbanding terbalik, semakin besar kadar fenol maka semakin kecil nilai pHnya. Nilai $\mathrm{pH}$ juga berpengaruh pada rendemen asap cair yang dihasilkan. Menurut [16], nilai $\mathrm{pH}$ dalam asap cair menunjukkan tingkat proses penguraian bahan baku secara pirolisis. Nilai $\mathrm{pH}$ yang rendah menunjukkan asap cair yang dihasilkan berkualitas tinggi dalam hal penggunaanya sebagai bahan pengawet dan daya simpan suatu produk dan sifat organoleptiknya [17], $\mathrm{pH}$ asap cair yang baik berkisar antara 1,5 - 3,7 karena pada kondisi $\mathrm{pH}$ yang rendah, mikroba yang berspora tidak dapat hidup dan berkembangbiak sehingga dapat berperan menghambat pertumbuhan mikroba pembusuk.

\subsection{Perbedaaan Struktur Kayu}

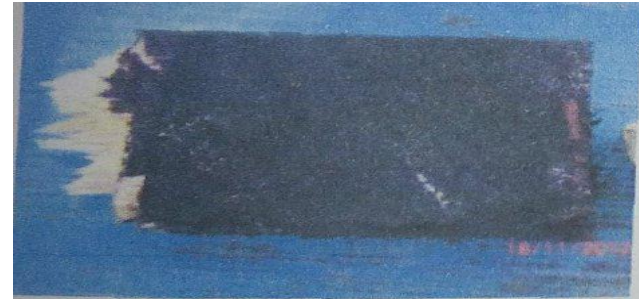

Gambar 3. Kayu yang diolesi asap cair

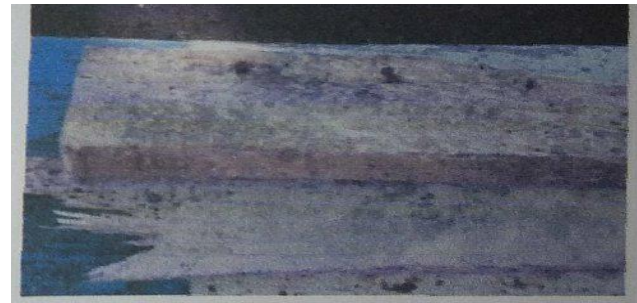

Gambar 4. Kayu yang tidak diolesi asap cair

Struktur kayu yang tidak memiliki serat akan menghasilkan kualitas yanng rendah dimana fungsi mekanisme kayu menjadi mudah diserang rayap dan jamur, kayu menjadi mudah rapuh. Sedangkan kayu yang dioleskan dengan asap cair memiliki struktur yang masih tetap utuh dan tidak mudah rapuh, hal ini dikarenakan kandungan fenol dan keasaman pada asap cair dapat mencegah pertumbuhan mikroba dan mikroorgnaisme dan dapat memperbaiki struktur dari kayu.

\section{KESIMPULAN}

Rendemen asap cair yang dihasilkan dengan panjang pipa penghubung $43 \mathrm{~cm}$ sebesar 19,5\% Kadar fenol dan $\mathrm{pH}$ adalah $1,15 \%$ dan 2,43 sedangkan dari proses pirolisis bambu dengan penggunaan pipa penghubung kondensor $43 \mathrm{~cm}$ diperoleh pula bau dan warna pada asap cair yang dihasilkan dimana memiliki warna coklat kemerahan dengan aroma asap yang sangat kuat. Sehingga asap cair yang dihasilkan baik digunakan dikarenakan memiliki nilai fenol yang tinggi dan juga nilai $\mathrm{pH}$ yang rendah dimana baik untuk digunakan. 


\section{DAFTAR PUSTAKA}

[1] Darmadji, P. 1995. Produksi asap cair dan sifat fungsionalnya [Laporan Penelitian]. Yogyakarta: Fakultas Teknologi Pertani-an, Universitas Gadjah Mada

[2] CIFOR dan Indonesia. 2012. "Kemitraan untuk Hutan dan Manusia". Pusat Penelitian Kehuanan Internasional (CIFOR). Bogor Indonesia.

[3] Kasmudjo, 2010, "Buku Ajar Mata Kuliah hasil Hutan Non Kayu”, Fakultas Kehutanan UGM, Yogyakarta.

[4] Komarayati S dan Santiyo Wibowo. 2015. "Karakteristik. Asap Cair dari Tiga Jenis Bambu (Characteristics of Liquid Smoke from Three Bamboo Species)". Jurnal Penelitian Hasil Hutan Vol. 33 No. 2. Bogor.

[5] Herliyana EN, Noverita, Lisdar IS. 2005. "Fungi pada Bambu Kuning (Bambusa vulgaris schard var. vitata) dan Bambu Hijau (Bambusa vulgaris schard var vulgaris) serta Tingkat Degradasi yang diakibatkannya". Jurnal Teknologi Hasil Hutan 18(1): 2-10.

[6] Widya. 2006. "Bambu Indonesia" tersedia pada bamboe Indonesia, Wordpress.com (Diakses pada tanggal 10 Juni 2017).

[7] Taufik Hidayat, Qomaruddin. 2015. "Analisa pengarub temperatur pirolisis dan bahan biomassa terbadap kapasitas hasil pada alat pembuat asap cair", Prosiding SNST ke-6, p.29-34, Fakultas Teknik Universitas Wahid Hasyim, Semarang.

[8] Girard, J.P. 1992. Smoking in Technology of Meat Products. New
York: Clermont Ferrand, Ellis Horwood.

[9] Abdul,dkk.2007. Karakterisasi Asap Cair Hasil Pirolisis Sampah Organik Padat (Characterization of Liquid Smoke Pyrolyzed From Solid Organic Waste)(http://www.repository.ipb.ac. id/). [online] diakses 19 Agustus 2108.

[10] Kausa. A. 2012. Analisa Kualitas Asap Cair dari Bagas, Blotong, Sekam Padi dan Jerami Padi. Laporan Penelitian Universitas Tribhuwana Tunggadewi Malang.

[11] Tranggono, S., B. Setiadji, P. Darmadji, Supranto, dan Sudarmanto. 1997. Identiflkasi asap cair dari berbagai jenis kayu dan tempurung kelapa. Jurnal Ilmu dan Teknologi Pangan 1(2): 15-24

[12] Demirbas, A. 2005. "Pyrolysis of ground beech wood in irregular beating rate conditions". Journal of Analytical Applied and Pyrolysis 73:39-43.

[13] Elssy, E, Olga Dasilva Martins. 2015. “ pemanfaatan tongkol jagung dan sekam padi menjadi asap cair menggunakan proses pirolisis." [Laporan penelitian]. Universitas Tribhuwana Tunggadewi Malang.

[14] Prananta, J. 2007. Pemanfaatan sabut dan tempurung kelapa serta cangkang sawit untuk pembuaatan asap cair sebagai pengawet makanan alami. [Skripsi]. Teknik Kimia Universitas Malikussaleh. Lhoksumawe

[15] Akbar, Awhu, Rio Paindoman, Pamilia Coniwanti. 2013. 'Pengaruh Variabel Waktu dan Temperatur Terbadap Pembuatan Asap Cair dari Limbab Kayu Pelawan (Cyanometra Cauliflora)". Jurnal 
Teknik Kimia Vol 19, No.1. Palembang.

[16] Yulistiani, R.1997. Kemampuan Penghambatan Asap Cair terhadap Pertumbuhan Bakteri Pathogen dan Perusak. Pada Lidah Sapi [Tesis]. Yogyakarta: Program Pasca-sarjana, Universitas Gadjah Mada.

[17] Haji, A.G., Mas’ud, Z. A., Lay, B. W., Sutjahjo, S.H. dan G. Pari (2012). Karakterisasi asap cair hasil pirolisis sampah organic padat. Journal.ipb.ac.id / index.php / jurnaltin / article / view / 4252 / 2890 [10 November 2012 ]. Bogor.

[18] Pujilestari, T . 2010. Analisa Sifat fisika Kimia dan anti bakteri asap cair cangkang kelapa sawit untuk pengawet pangan. Samarinda. JRTI Vol. 4, N0. 8. 